\title{
INFLUENCE OF SUGARS ON THE FOLIAR UPTAKE OF BENTAZONE AND GLYPHOSATE
}

\author{
Z.Q. LIU \\ Plant Protection Chemistry ${ }_{N Z}$,Forest Research, Private Bag 3020, Rotorua \\ Corresponding author: Zhiqian.Liu@forestresearch.co.nz
}

\begin{abstract}
The effect of sugars on the uptake of bentazone and glyphosate into bean (Vicia faba) and wheat (Triticum aestivum) foliage was studied. The addition of $0.5 \%$ glucose or sucrose significantly increased the uptake of bentazone into bean and wheat leaves. This effect was also observed in the presence of a surfactant, especially in wheat. Glucose and sucrose also improved the uptake of glyphosate into wheat leaves, especially in combination with surfactants of low ethylene oxide content. When used at $2 \%$ concentration, both sugars completely overcame the antagonistic effect of an organosilicone surfactant (Silwet L-77) on glyphosate uptake into wheat leaves. The results are discussed in relation to the solute dose on the leaf surface as influenced by surfactants and sugars.
\end{abstract}

Key words: glucose, sucrose, uptake, herbicide, surfactant.

\section{INTRODUCTION}

Previous work (Liu \& Zabkiewicz 1997, 1998) has demonstrated that the uptake of glyphosate into grass species is dependent on the concentration (or dose) of active ingredient (ai) on the leaf surface. Surfactants, such as Silwet L-77, which cause extensive droplet spreading on grass foliage and reduce the ai dose on the leaf surface, also reduce glyphosate uptake.

The reason why higher glyphosate dose on a leaf surface produces greater percentage uptake of this herbicide remains unclear. It is known that the uptake of xenobiotics into plant foliage is a diffusion process. According to Fick's diffusion law, the amount of glyphosate that diffuses into leaf tissues over a specific time will be greater when a higher ai dose is formed on the leaf surface (due to higher concentration gradient between the donor and the receiver). However, the percentage uptake of the herbicide should not be affected by changing the ai dose. Clearly the diffusion law alone cannot explain this dosedependence character in glyphosate uptake.

It is known that cuticular transpiration is commonplace in herbaceous plants. This water flow from the internal tissues to the surface of plant leaves may contribute to the continued dissolution of pesticide deposits and facilitate their uptake. Water diffusion may be greater towards a surface with a higher glyphosate dose (creating a higher osmotic pressure), thereby extending the duration of the uptake process, and consequently achieving a higher percentage uptake. Based on this assumption, any osmotically active compounds may be able to improve pesticide uptake through stimulating water flow to the leaf surface. Such a hypothesis was tested in this work by studying the effect of sugars (glucose and sucrose) on the uptake of bentazone and glyphosate into two plant species, bean and wheat.

Plants

\section{MATERIALS AND METHODS}

Bean (Vicia faba, cv. Evergreen) and wheat (Triticum aestivum, cv. Advantage) seedlings were raised from seed in $70 \mathrm{~mm}$ square pots containing a peat-based potting mix ("Bloom", Yates NZ Ltd) in a controlled environment $\left(20^{\circ} \mathrm{C} / 15^{\circ} \mathrm{C}\right.$, day/night temperature; $70 \% \mathrm{RH} ; 12 \mathrm{~h}$ photoperiod with light intensity ca $500 \mu \mathrm{mol} / \mathrm{m}^{2} / \mathrm{s}$. Four week-old bean and wheat plants were used for the experiments.

New Zealand Plant Protection 55:159-162 (2002) 


\section{Chemicals}

Two surfactants, Lutensol AO $5\left(\mathrm{C}_{13} / \mathrm{C}_{15}\right.$ linear alcohol ethoxylate, mean ethylene oxide (EO) content $=5$, BASF, Germany) and Silwet L-77 (trisiloxane ethoxylate, mean EO content $=8$, Witco, USA) were used in this study.

${ }^{14} \mathrm{C}$-Glyphosate (specific activity $1.9 \mathrm{GBq} / \mu \mathrm{mol}$, Amersham) and ${ }^{14} \mathrm{C}$-bentazone (specific activity $1.2 \mathrm{GBq} / \mu \mathrm{mol}$, BASF, Germany) were added respectively to solutions of unlabelled glyphosate (isopropylamine salt) or bentazone (sodium salt) of the required concentrations, immediately before use. Aqueous dispersions of surfactants or/and sugars were then added so that the treatment formulations all contained $0.2 \%$ ai for both herbicides.

Droplet spread area measurement

Droplets $(0.24 \mu \mathrm{l})$ of treatment formulations containing $0.5 \%$ fluorescent dye (Blankophor, Bayer) were applied to the adaxial surfaces of bean or wheat leaves. The spread area was measured using a Digital Optics V++ image analysis system. A minimum of eight replicates were used for each set of determinations. Only the average values $( \pm \mathrm{SE})$ are presented.

Determination of glyphosate and bentazone uptake

Twelve droplets $(0.24 \mu \mathrm{l})$ of treatment formulations containing ${ }^{14} \mathrm{C}$-glyphosate or ${ }^{14} \mathrm{C}$-bentazone (10000-15000 dpm) were applied by microsyringe to the adaxial leaf surface of bean (a single third leaf) or wheat (the youngest fully expanded leaf) plants. Each treatment consisted of five replicates of individual plants. Uptake was determined by washing residual herbicides from the treated leaf surfaces at $24 \mathrm{~h}$ after treatment and calculating the amount absorbed as described by Gaskin (1995).

All uptake results were subjected to analysis of variance and treatments were compared using least significant difference (LSD) tests.

\section{RESULTS}

Effect of sugars on the uptake of bentazone

The intrinsic uptake of bentazone was low, with only $21 \%$ and $13 \%$ of applied dose being taken up by bean and wheat leaves respectively after $24 \mathrm{~h}$ (Table 1). The addition of glucose or sucrose significantly increased bentazone uptake into both species. The enhancing effect of the sugars on bentazone uptake was more pronounced on wheat foliage.

TABLE 1: Effect of sugars on droplet spread area $\left(\mathrm{mm}^{2} \pm\right.$ standard error of the mean), ai dose $\left(\mu \mathrm{g} / \mathrm{mm}^{2}\right)$ and bentazone uptake $(\%)$ at $24 \mathrm{~h}$ after treatment.

\begin{tabular}{|c|c|c|c|c|c|c|}
\hline \multirow[b]{2}{*}{ Treatments } & \multicolumn{3}{|c|}{ Bean } & \multicolumn{3}{|c|}{ Wheat } \\
\hline & $\begin{array}{l}\text { Spread } \\
\text { area }\end{array}$ & $\begin{array}{c}\text { Dose of } \\
\mathrm{ai}^{1}\end{array}$ & Uptake & $\begin{array}{l}\text { Spread } \\
\text { area }\end{array}$ & $\begin{array}{c}\text { Dose of } \\
\mathrm{ai}^{1}\end{array}$ & Uptake \\
\hline Bentazone & $1.8 \pm 0.2$ & 0.27 & 21 & $0.8 \pm 0.1$ & 0.60 & 13 \\
\hline Bentazone $+0.5 \%$ glucose & $1.9 \pm 0.4$ & 0.25 & 31 & $0.9 \pm 0.1$ & 0.53 & 34 \\
\hline Bentazone $+0.5 \%$ sucrose & $2.3 \pm 0.3$ & 0.21 & 34 & $0.9 \pm 0.1$ & 0.53 & 28 \\
\hline Bentazone $+0.2 \% \mathrm{AO} 5$ & $2.0 \pm 0.2$ & 0.24 & 46 & $7.9 \pm 1.1$ & 0.06 & 30 \\
\hline $\begin{array}{l}\text { Bentazone }+0.2 \% \text { AO } 5+ \\
0.5 \% \text { glucose }\end{array}$ & $2.1 \pm 0.3$ & 0.23 & 64 & $7.3 \pm 1.3$ & 0.07 & 66 \\
\hline $\begin{array}{l}\text { Bentazone }+0.2 \% \mathrm{AO} 5+ \\
0.5 \% \text { sucrose }\end{array}$ & $1.9 \pm 0.2$ & 0.25 & 60 & $7.9 \pm 1.4$ & 0.06 & 52 \\
\hline Bentazone + 0.1\%L-77 & $34.0 \pm 5.3$ & 0.014 & 27 & $12.8 \pm 1.6$ & 0.038 & 10 \\
\hline $\begin{array}{l}\text { Bentazone }+0.1 \% \mathrm{~L}-77+ \\
2 \% \text { glucose }\end{array}$ & $30.5 \pm 3.3$ & 0.016 & 45 & $13.9 \pm 1.0$ & 0.035 & 49 \\
\hline $\begin{array}{l}\text { Bentazone }+0.1 \% \mathrm{~L}-77+ \\
2 \% \text { sucrose }\end{array}$ & $28.6 \pm 4.7$ & 0.017 & 43 & $13.9 \pm 0.7$ & 0.035 & 32 \\
\hline LSD $(\mathrm{P}<0.05)$ & & & 9 & & & 6 \\
\hline
\end{tabular}

${ }^{1}$ Amount of active ingredient of herbicide $(\mu \mathrm{g})$ in one droplet/spread area $\left(\mathrm{mm}^{2}\right)$. 
The presence of AO 5 surfactant also markedly improved the uptake of bentazone, with percentage uptake at $24 \mathrm{~h}$ after treatment being increased to $46 \%$ on bean and $30 \%$ on wheat foliage. However, bentazone uptake was further enhanced when the sugars were used in combination with AO 5. Uptake reached 64\% and 66\% into the two species respectively.

L-77 had no positive effect on bentazone uptake when used alone, but significantly enhanced the uptake into both species, when combined with glucose or sucrose.

Effect of sugars on the uptake of glyphosate

Without surfactants, sugars had no significant effect on glyphosate uptake into bean and only slightly improved uptake into wheat leaves (Table 2).

TABLE 2: Effect of sugars on droplet spread area $\left(\mathrm{mm}^{2} \pm\right.$ standard error of the mean), ai dose $\left(\mu \mathrm{g} / \mathrm{mm}^{2}\right)$ and glyphosate uptake $(\%)$ at $24 \mathrm{~h}$ after treatment.

\begin{tabular}{|c|c|c|c|c|c|c|}
\hline \multirow[b]{2}{*}{ Treatments } & \multicolumn{3}{|c|}{ Bean } & \multicolumn{3}{|c|}{ Wheat } \\
\hline & $\begin{array}{l}\text { Spread } \\
\text { area }\end{array}$ & $\begin{array}{l}\text { Dose of } \\
\text { ai }\end{array}$ & Uptake & $\begin{array}{l}\text { Spread } \\
\text { area }\end{array}$ & $\begin{array}{c}\text { Dose of } \\
\text { ai }\end{array}$ & Uptake \\
\hline Glyphosate & $2.2 \pm 0.2$ & 0.22 & 33 & $0.7 \pm 0.1$ & 0.69 & 23 \\
\hline Glyphosate $+0.5 \%$ glucose & $2.0 \pm 0.2$ & 0.24 & 39 & $0.9 \pm 0.2$ & 0.53 & 32 \\
\hline Glyphosate $+0.5 \%$ sucrose & $2.3 \pm 0.1$ & 0.21 & 35 & $0.8 \pm 0.1$ & 0.60 & 31 \\
\hline Glyphosate $+0.2 \%$ AO 5 & $2.1 \pm 0.1$ & 0.23 & 42 & $5.4 \pm 1.0$ & 0.09 & 29 \\
\hline $\begin{array}{l}\text { Glyphosate }+0.2 \% \text { AO } 5+ \\
0.5 \% \text { glucose }\end{array}$ & $2.0 \pm 0.2$ & 0.24 & 52 & $5.5 \pm 0.5$ & 0.09 & 49 \\
\hline $\begin{array}{l}\text { Glyphosate }+0.2 \% \text { AO } 5+ \\
0.5 \% \text { sucrose }\end{array}$ & $2.0 \pm 0.2$ & 0.24 & 51 & $5.5 \pm 1.0$ & 0.09 & 50 \\
\hline Glyphosate + 0.1\%L-77 & $32.4 \pm 1.9$ & 0.015 & 19 & $12.3 \pm 1.9$ & 0.039 & 14 \\
\hline $\begin{array}{l}\text { Glyphosate }+0.1 \% \mathrm{~L}-77+ \\
2 \% \text { glucose }\end{array}$ & $30.1 \pm 1.8$ & 0.016 & 31 & $12.8 \pm 1.7$ & 0.038 & 41 \\
\hline $\begin{array}{l}\text { Glyphosate }+0.1 \% \mathrm{~L}-77+ \\
2 \% \text { sucrose }\end{array}$ & $28.9 \pm 1.9$ & 0.017 & 33 & $12.7 \pm 1.1$ & 0.038 & 43 \\
\hline $\operatorname{LSD}(\mathrm{P}<0.05)$ & & & 8 & & & 7 \\
\hline
\end{tabular}

The addition of AO 5 slightly increased glyphosate uptake into bean but had no effect on its uptake into wheat. Greatest uptake (52\% on bean and $50 \%$ on wheat) was obtained when sugars were added together with AO 5. L-77 reduced glyphosate uptake into both species when used alone. The addition of glucose or sucrose overcame this antagonistic effect.

\section{DISCUSSION}

It has been reported that glycerol, a well-known humectant, improved aminotriazole penetration into bean leaves (Cook et al. 1977) and glyphosate uptake into wheat leaves (Gaskin \& Stevens 1993). Sugars are generally not considered to have hygroscopic properties and their effect on pesticide uptake has not been tested previously.

Sugar molecules had no significant effect on droplet spread areas either in the presence or absence of surfactants. Thus, their enhancing effect on herbicide uptake was not achieved by reducing the spread area and increasing the ai dose on the leaf surface.

Sugars are known to be osmotically active. When applied to plant foliage, they may stimulate water diffusion to the leaf surface and facilitate pesticide uptake. Theoretically, glucose should be more efficient than sucrose in enhancing uptake when used at the same concentration due to its lower molecular weight and hence higher osmotic pressure; this was found only in some cases in the current experiment. Such sugars may also penetrate into plant leaves and glucose, being a smaller molecule, should penetrate faster 
than sucrose. As a result, the molar concentration of unabsorbed glucose, which determines the osmotic pressure, may not be always greater than that of sucrose.

It was also observed that the effect of sugars on uptake varied with herbicide and plant species. Indeed, the uptake of these water-soluble chemicals is determined by two factors: ai dissolution and cuticular penetration. Sugars, which are expected to draw water to the leaf surface, are likely to be more efficient at promoting uptake when the solute dissolution is the limiting factor, such as in the case of bentazone (which has lower water solubility). They can also significantly improve the uptake of a hydrophilic compound, like glyphosate applied with spreading surfactants on wheat leaves, by increasing the total solute dose and hence creating a higher osmotic pressure. In contrast, sugars may have limited effect on uptake when the solute penetration is the limiting factor, such as in the case of glyphosate applied on bean leaves. Combining surfactants and sugars may be required to maximise their effect on pesticide uptake.

\section{REFERENCES}

Cook, G.T.; Babiker, A.G.T.; Duncan, H.J. 1977: Penetration of bean leaves by aminotriazole as influenced by adjuvants and humidity. Pesticide Sci. 8: 137-146.

Gaskin, R.E. 1995: Effect of organosilicone surfactants on the foliar uptake of herbicides: stomatal infiltration versus cuticular penetration. In: Gaskin, R.E. ed. Proc. 4th Int. Symp. on Adjuvants for Agrochemicals, Melbourne. Pp. 243-248.

Gaskin, R.E.; Stevens, P.J.G. 1993: Antagonism of the foliar uptake of glyphosate into grasses by organosilicone surfactants. Part 2: Effects of surfactant structure and glycerol addition. Pesticide Sci. 38: 193-200.

Liu, Z.Q.; Zabkiewicz, J.A. 1997: Cuticular uptake of glyphosate into wheat with organosilicone surfactant. Proc. 50 ${ }^{\text {th }}$ N.Z. Plant Prot. Conf.: 129-133.

Liu, Z.Q.; Zabkiewicz, J.A. 1998: Organosilicone surfactant mediated cuticular uptake of glyphosate into grasses. In: McMullan, P. ed. Proc. 5th Int. Symp. on Adjuvants for Agrochemicals, Memphis. Pp. 119-124. 